\title{
Adding wheat to a pre-partum diet of Holstein cows favours post-partum protein utilization and benefits calcium status
}

\author{
H.M. Alamouti ${ }^{1}$, H. Amanlou ${ }^{1}$, K. Rezayazdi ${ }^{2}$, M. Vazirigohar ${ }^{3}$, M.Z. Ihsan ${ }^{4}$ \& M.N. Tahir ${ }^{5 \#}$ \\ ${ }^{1}$ Department of Animal Science, Faculty of Agriculture, University of Zanjan, 45371-38111, Zanjan, Iran \\ ${ }^{2}$ Department of Animal Science, University College of Agriculture and Natural Resources. University of Tehran, 31587- \\ 77871, Karaj, Iran \\ ${ }^{3}$ Zist Dam Group, 31476-66544, Alborz, Iran \\ ${ }^{4}$ Cholistan Institute of Desert Studies, The Islamia University of Bahawalpur-63100, Pakistan \\ ${ }^{5}$ University College of Veterinary and Animal Sciences, The Islamia University of Bahawalpur-63100, Bahawalpur, \\ Pakistan
}

(Received 28 February 2020; Accepted 10 July 2020; Published 24 September 2020)
Copyright resides with the authors in terms of the Creative Commons Attribution 4.0 South African Licence. See: http://creativecommons.org/licenses/by/4.0/za
The user may copy, distribute, transmit and adapt the work, but must recognise the authors and the South African Journal of Animal Science.

\begin{abstract}
This study evaluated the effects of replacing corn with wheat on the lactation performance, ruminal fermentation, plasma metabolites and hormonal profiles of multiparous Holstein cows. Thirty-four multiparous cows were divided into two equal groups, based on parity, body condition score, and bodyweight. The basal diet was supplemented with $186 \mathrm{~g} / \mathrm{kg}$ corn or wheat, and was offered from day $-28( \pm 7)$ relative to the date of expected calving. After calving, all cows received the same diet for four weeks (day +28$)$. The wheat diets increased $(P<0.05)$ the body condition score in the peri-parturient period and caused greater changes in dry matter intake and bodyweight post-partum, with no differences in energy balance compared with the corn diets. Further, the wheat increased $(P<0.05)$ the concentration of propionate in the rumen, thus reducing the ratio of acetate to propionate, and produced $(P<0.05)$ more milk and milk protein, but had reduced levels of urea nitrogen in the milk and serum. Similarly, the wheat diets increased $(P<0.05)$ the plasma concentrations of albumin and glucose, and reduced $(P<0.05)$ triglycerides with no effect $(P>0.10)$ post partum on insulin, cortisol, $\beta$-hydroxybutyric acid and aspartate aminotransferase. The replacement of corn with wheat increased $(P<0.05)$ plasma calcium and reduced non-esterified fatty acids around calving (day $0 \pm 1$ ) and post-partum (days 0 to +28 ), and reduced urinary $\mathrm{pH}$ during the last week relative to the date of expected calving.
\end{abstract}

Keywords: calving, energy balance, grain source, peri-parturient period

\#Corresponding author zahid.ihsan@iub.edu.pk

\section{Introduction}

Feeding dairy cows during the peri-parturient period for optimum post-partum performance is challenging, because rumen capacity and dry matter intake (DMI) are reduced owing to the space that is required for the gravid uterus during late gestation (Stanley et al., 1993). In addition, peri-parturient nutrition is complicated by marked changes in the energy requirements that result from parturition and the onset of lactation (Drackley, 1999). The difference between energy intake through diet and output through milk production puts the cows into negative energy balance from parturition to 35 days post-partum (Wankhade et al., 2017). This deficiency in the net energy balance predisposes lactating animals to oxidative stress (Sharma et al., 2011) and leads to metabolic and immunological disorders such as ketosis, fatty liver syndrome, and milk fever (hypocalcaemia). Therefore, a smooth transition from pregnancy to lactation is necessary to minimize health disorders and to optimize productivity and profitability.

Hypocalcaemia occurs from days 0 to 3 post-partum, and is a nutritional deficiency that is characterized by a reduction in serum calcium (Ca) concentration that does not return to normal for several days (Wankhade et al., 2017). Compared with normal serum Ca concentration ( $>2.25 \mathrm{mmol} / \mathrm{L}$ ), this condition can be manifest as subclinical hypocalcaemia $(1.75-2.25 \mathrm{mmol} / \mathrm{L}$ serum $\mathrm{Ca})$ or clinical hypocalcaemia $(0.50$ $-1.75 \mathrm{mmol} / \mathrm{L}$ serum Ca) which is commonly called milk fever (Merck Veterinary Manual, 2012; Martinez et 
al., 2012). Calcium is important in immune cell activation and smooth functioning of muscles (Goff, 2008). Hypocalcaemia may lower the $\mathrm{Ca}$ release in the cells in response to impaired immune activation signals (Kimura et al., 2006). The incidence of clinical hypocalcaemia in dairy cows is as common as $3.45 \%$ in North America and $6.17 \%$ in Europe, with no data having been reported for Asia and Africa (DeGaris \& Lean, 2008). Several pre- and post-partum remedies have been employed to reduce the chances of hypocalcaemia in dairy cattle. The most popular and most widely adopted remedies include the manipulation of the dietary cation-anion difference (Megahed et al., 2018; Santos et al., 2019) by providing supplemental minerals pre- (Kronqvist et al., 2011) or post-partum (Martinez et al., 2016a; 2016b) or feed supplements such as NutriCAB® (Babir et al., 2017). The use of exogenous feed supplements always results in additional costs and makes milk production less economical.

Protein and starch in wheat are rapidly fermentable in the rumen (Fox et al., 2004). Wheat has a low dietary cation-anion difference relative to other cereal grains (NRC, 2001) and high acidogenicity (Wadhwa, et al., 2001). But wheat is seldom fed to dairy cows because of concern that it may contribute to the development of sub-acute ruminal acidosis (Plaizier et al., 2008). On the other hand, the inclusion of wheat grain in their diets has successfully maintained production and metabolic parameters in peri-parturient dairy cows (Amanlou et al., 2008; Nikkhah et al., 2011; Alamouti et al., 2009). Therefore, it was hypothesized that wheat grain in pre-partum diets would mimic the exogenous acidogenic sources in peri-parturient diets, resulting in reduced dependency on exogenous supplements, by increasing the rumen propionate production, reducing extra-cellular alkalinity, and maintaining $\mathrm{Ca}$ homeostasis, thus reducing the chances of hypocalcaemia and other metabolic disorders around calving. In this research, corn was replaced with wheat in the diet for multiparous Holstein cows during the peri-parturient period, and the effects of this replacement were evaluated on DMI, lactation performance, ruminal fermentation, plasma metabolites, and hormonal profiles.

\section{Materials and Methods}

The experiment was performed with a completely randomized design to describe the performance of Holstein cows when supplemented with corn or wheat during the pari-parturient period. All experimental procedures were approved by the Animal Experiment Committee of the University of Tehran (Alborz, Iran). Thirty-four Holstein cows were selected within the range of bodyweight $787 \pm 80 \mathrm{~kg}$, body condition score $3.37 \pm 0.49$, and parity $3.22 \pm 1.47$. The cows were divided into two equal groups $(n=17)$ and both groups were supplied with an isocaloric and isonitrogenous diet of alfalfa hay as basal feed. The groups were supplemented with equal amounts $(186 \mathrm{~g} / \mathrm{kg}$ as total mixed ration) of corn or wheat from day $-28( \pm 7)$ of expected calving until the day of actual calving.

The lactation diet, which was same for all the cows, was started immediately (day 0 ) after calving and continued for the next four weeks (day +28 ). From the start of the experiment, all cows were group fed until one week (day -7) before the expected calving. The cows were fed individually for one week before (day -7) and one week after (day +7$)$ calving. All cows were then group fed from the second week (day +7$)$ after calving until the end of the fourth week (day +28$)$. The pre-partum and post-partum diets were formulated with the Cornell-Penn-Miner system (CPM Dairy, version 3.0.6) with a forage to concentrate ratio of 65 to 35 and 40 to 60 for the pre- and post-partum periods (Table 1). The cows were fed twice daily during the prepartum period (11 h00 and 18h00) and thrice daily during the post-partum period (07h00, 15h00, and 23h00). All cows were housed in free-stall barns with free access to drinking water. Cows were milked three times a day $(07 \mathrm{~h} 00,15 \mathrm{~h} 00$, and $23 \mathrm{~h} 00)$ in a tandem milking parlour.

Each day, samples of the diet and orts were collected and the feed consumption by each cow was recorded. These samples were oven-dried for 48 hours at $60^{\circ} \mathrm{C}$ and stored at $-20^{\circ} \mathrm{C}$. After four weeks of the pre- and post-partum periods, all samples from the same period were mixed to prepare three composite samples for each ration and were analysed in triplicate. Each animal was weighed three times (day -28, day +1 and day +28 ) relative to the date of expected calving. Cow body score condition was evaluated weekly using a scale from 1 to 5 (Wildman et al., 1982) by three skilled individuals throughout the study period.

The feed samples were analysed for dry matter, crude protein, ash and ether extract (AOAC, 2000). Neutral and acid detergent fibres were determined and expressed exclusive of residual ash (VanSoest et al., 1991). The protein content was determined by the Kejeldahl method from fibre residue samples (Licitra et al., 1996). Calcium, phosphorus $(\mathrm{P})$, magnesium $(\mathrm{Mg})$, sodium $(\mathrm{Na})$, and potassium $(\mathrm{K})$ were measured with an atomic absorption spectrophotometer (Shimadzu, AA-670, Kyoto, Japan). Table 2 shows the chemical composition of the ingredients used in formulating the diets. The energy balance (Mcal $/ \mathrm{kg}$ ) of each cow was calculated from the dry matter content of the diet (NRC, 2001):

$$
\begin{aligned}
& E B_{\text {Prepartum }}=N E I-\left(N E_{\text {Maintenance }}+N E_{\text {Pregnancy }}\right) \\
& E B_{\text {Postpartum }}=N E I-\left(N E_{\text {Maintenance }}+N E_{\text {Lactation }}\right)
\end{aligned}
$$


The milk yield from each lactating cow was recorded daily. Milk samples were composited from three consecutive milkings and preserved with potassium dichromate. These samples were tested for total solids, lactose, protein, fat, milk urea nitrogen (MUN), and somatic cell count with Milko Scan ${ }^{\mathrm{TM}} 4000$ (Foss ${ }^{\circledR}$ Electric, Denmark). Fat-corrected milk yield (Brog, 1971) and energy-corrected milk yield (Baevre et al., $1988)$ were calculated from these values. The somatic cell counts were transformed as $\left(\left(\log _{10}(\mathrm{SCC} / 1000)-\right.\right.$ $2)\left(\log _{10}(2)\right)+3$, as suggested by Thurmond, 1990).

Table 1 Ingredient and nutrient composition of diets offered to pari-parturient Holstein cows

\begin{tabular}{|c|c|c|c|}
\hline \multirow{2}{*}{ Ingredients, g/kg DM } & \multicolumn{2}{|c|}{ Pre-partum diets } & \multirow{2}{*}{ Lactation diet } \\
\hline & Corn & Wheat & \\
\hline Alfalfa hay & 646.3 & 646.3 & 396.8 \\
\hline Rolled corn & 185.7 & & 138.9 \\
\hline Rolled wheat & & 185.7 & \\
\hline Rolled barley & & & 138.9 \\
\hline Soybean meal & 112.9 & 92.9 & 174.1 \\
\hline Cottonseed & 14.5 & 34.7 & 55.5 \\
\hline Beet pulp & 26.0 & 26.0 & 20.8 \\
\hline Fish meal & 5.2 & 5.2 & 10.9 \\
\hline Poultry meat and bone meal & & & 20.8 \\
\hline Ca salt of fatty acid & & & 17.9 \\
\hline Calcium carbonate & 3.5 & 3.5 & 6.0 \\
\hline Sodium bicarbonate & & & 10.9 \\
\hline Magnesium oxide & & & 1.5 \\
\hline Sodium chloride & & & 2.0 \\
\hline Vitamin and mineral $^{1}$ & 5.7 & 5.7 & 5.0 \\
\hline Forage to concentrate ratio & 65:35 & 65:35 & 40:60 \\
\hline \multicolumn{4}{|l|}{ Nutrient composition, g/kg DM } \\
\hline Net energy intake ${ }^{2}$, Mcal $/ \mathrm{kg}$ & $1.45 \pm 0.02$ & $1.44 \pm 0.01$ & $1.69 \pm 0.02$ \\
\hline Crude protein & $168 \pm 3.0$ & $167 \pm 3.1$ & $197 \pm 2.3$ \\
\hline Rumen degradable protein ${ }^{2}$ & $113 \pm 2.0$ & $114 \pm 2.2$ & $125 \pm 2.3$ \\
\hline Neutral detergent fibre & $355 \pm 7.1$ & $362 \pm 6.1$ & $303 \pm 5.3$ \\
\hline Non-fibre carbohydrates ${ }^{3}$ & $380 \pm 6.3$ & $375 \pm 4.2$ & $386 \pm 4.4$ \\
\hline Ether extract & $26 \pm 0.8$ & $27 \pm 0.9$ & $51 \pm 0.5$ \\
\hline Ash & 71 & 69 & 63 \\
\hline $\mathrm{Ca}$ & $8.8 \pm 0.6$ & $8.8 \pm 0.5$ & $10.7 \pm 0.5$ \\
\hline$P$ & $2.9 \pm 0.2$ & $3.0 \pm 0.2$ & $3.4 \pm 0.2$ \\
\hline $\mathrm{Mg}$ & $2.2 \pm 0.3$ & $2.3 \pm 0.1$ & $3.8 \pm 0.1$ \\
\hline $\mathrm{K}$ & $17.5 \pm 0.5$ & $17.0 \pm 0.4$ & $17.2 \pm 0.4$ \\
\hline $\mathrm{Na}$ & $3.5 \pm 0.2$ & $4.0 \pm 0.2$ & $6.7 \pm 0.2$ \\
\hline
\end{tabular}

'Vitamin A: 800000 IU; vitamin D: 230000 IU; vitamin E:12000 IU; Ca: 196 g; P: 96 g; Mg: 71 g ;Fe: 3 g; Cu: 0.3 g; Mn: 2 $\mathrm{g} ; \mathrm{Zn}: 3 \mathrm{~g} ; \mathrm{Co}$ :, $0.1 \mathrm{~g} ; \mathrm{l}: 0.1 \mathrm{~g}$; and Se: $0.1 \mathrm{~g}$ per $\mathrm{kg}$ of DM

2 Estimated using Cornell-Penn-Miner system (Dairy, version 3.0.6.), ${ }^{3} \mathrm{NFC}=100-(\mathrm{NDFn}+\mathrm{CP}+\mathrm{EE}+$ ash). NFC: nonfibre carbohydrates, Ca: calcium, P: phosphorus, Mg: magnesium, K: potassium, Na: sodium, DM: dry matter

The $\mathrm{pH}$ was determined from urine and rumen fluid samples. Urine samples were collected one week before the expected calving. The rumen fluid samples were collected 17 days before the expected calving and 17 days afterwards with an oesophageal tube fitted with a strainer to which vacuum pressure was 
applied. The initial $200 \mathrm{~mL}$ sample was discarded to avoid contamination with saliva. The stained samples were used to measure rumen $\mathrm{pH}$ (ABB Kent Taylor, Kent EIL, England). Volatile fatty acids (VFAs) were determined with gas chromatography (Philips, Varian 3700, serial number PU 4410, Brockville, Ontario, Canada) from the rumen samples that had been mixed with $25 \%$ metaphosphoric acid and frozen before VFA analysis (Ottenstein \& Bertley, 1971).

Three blood samples were collected from the coccygeal vein of each cow into heparinized evacuated tubes (Pars Azmon, Tehran, Iran) on day -28 , day -7 , day -1 , day 0 , day +1 , day +7 , and day +28 ) relative to the date of expected calving. Within one hour of sampling, these samples were centrifuged at $3000 \times$ for 15 minutes (Sigma 101 Germany). Plasma was harvested and aliquots were stored at $-20{ }^{\circ} \mathrm{C}$ until further analysis. Various bioassays were performed with commercial kits to determine the concentrations of nonesterified fatty acid and hn $\beta$-hydroxybutyric acid (Randox Laboratories Ltd., Crumlin, United Kingdom, Cat. no. RB1007). Similar procedures were followed to determine the blood $\mathrm{Ca}$, urea, cholesterol, glucose, triglyceride, and aspartate aminotransferase (Pars Azmon, Tehran, Iran). A radioimmunoassay kit were used to measure blood insulin and cortisol (INSIK-5, P2796 and Gamma Coat cortisol, CA 1529E, Diasorin). All metabolic profile measurements were performed in accordance with the guidelines of the manufacturers.

The data were recorded and analysed separately for the pre-partum and post-partum periods with SAS software (SAS Institute, Inc. Cary, North Carolina, USA). For those traits that were measured more than once the general linear model used to analyse the data was:

$$
Y_{i j k}=\mu+T_{i}+W_{j}+T W_{i j}+C_{k}\left(T_{i}\right)+\varepsilon_{i j k}
$$

where: $Y_{i j k}$ is the dependent variable,

$\mu$ is the overall mean,

$T_{i}$ is the effect of treatment $i$,

$W_{j}$ is the effect of time $j$,

$T W_{i j}$ is the interaction between time $j$ and treatment $i$,

$C_{k}\left(T_{i}\right)$ is the effect of cow $k$, nested in the treatment, and

$\varepsilon_{i j k}$ is the residual error.

Data without repeated measurements were analysed through the following model:

$$
Y_{i k}=\mu+T_{i}+\varepsilon_{i k}
$$

where: $Y_{i k}$ is the dependent variable and

$\varepsilon_{i k}$ is the residual error.

The treatment effects were considered significant when the associated $P$-value was $\leq 0.05$, and trends were discussed for those effects where $P \leq 0.10$.

\section{Results and Discussion}

The effects of the experimental diets were non-significant for energy balance during the pre-partum period (Table 2) and the post-partum period (Table 3 ). The wheat-based diets increased $(P<0.05)$ the body condition score in the peri-parturient period and caused greater changes in DMI and bodyweight post-partum than the corn diets. In contrast, corn-based diets increased $(P<0.05) \mathrm{DMI}$ and net energy intake pre-partum with smaller differences in bodyweight change post-partum. Significant differences were observed between the periods when the results of the diets were averaged. Body condition score decreased after parturition relative to before calving. In contrast, the cows lost less weight after calving. Daily matter intake, DMI change and net energy intake were improved, whereas the energy balance was reduced post-partum compared with the pre-partum period. 
Table 2 Pre-partum dry matter intake, energy balance, body condition score and bodyweight change parameters of dairy cows fed corn- or wheat-based rations

\begin{tabular}{|c|c|c|c|c|c|c|c|}
\hline \multirow{2}{*}{ Item } & \multicolumn{4}{|c|}{ Pre-partum diets } & \multicolumn{3}{|c|}{$P$-values } \\
\hline & Corn & Wheat & SE & RMSE & Diet & Time & $\begin{array}{l}\text { Diet } \times \\
\text { time }\end{array}$ \\
\hline \multicolumn{8}{|c|}{ Days relative to expected calving $(-28$ to -8$)$} \\
\hline BCS & 3.35 & 3.44 & 0.19 & 0.13 & 0.01 & 0.01 & 0.67 \\
\hline BCS change $^{1}$ & -0.04 & 0.00 & 0.04 & 0.18 & 0.45 & 0.03 & 0.23 \\
\hline Initial BW, kg & 796.58 & 780.56 & 22.30 & 83.60 & 0.89 & 0.01 & 0.20 \\
\hline$B W$ change $^{2}, \mathrm{~kg}$ & -78.58 & -79.45 & 1.36 & 5.08 & 0.56 & 0.01 & 0.38 \\
\hline \multicolumn{8}{|c|}{ Days relative to expected calving $(-7$ to -1$)$} \\
\hline DMI, kg/day & 11.11 & 10.67 & 0.14 & 0.55 & 0.03 & 0.01 & 0.66 \\
\hline $\mathrm{DMI}_{\text {change }}{ }^{3}, \mathrm{~kg}$ & -3.22 & -3.77 & 0.26 & 0.98 & 0.53 & 0.01 & 0.53 \\
\hline NEl intake, Mcal/day & 17.22 & 16.33 & 0.23 & 0.86 & 0.01 & 0.03 & 0.34 \\
\hline $\mathrm{EB}^{4}, \mathrm{Mcal} / \mathrm{day}$ & 1.58 & 0.92 & 1.20 & 1.53 & 0.31 & 0.02 & 0.45 \\
\hline BCS & 3.33 & 3.41 & 0.11 & 0.15 & 0.24 & 0.04 & 0.22 \\
\hline
\end{tabular}

Table 3 Post-partum dry matter intake, energy balance, body condition score and bodyweight change of dairy cows fed corn or wheat-based rations in the pre-partum period

\begin{tabular}{lccccccc}
\hline \multirow{2}{*}{ Item } & \multicolumn{3}{c}{ Pre-partum diet } & \multicolumn{3}{c}{$P$-values } \\
\cline { 2 - 6 } & Corn & Wheat & SE & RMSE & Diet & Time & Diet $\times$ Time \\
\hline Days relative to expected calving $(+1$ to +7$)$ & & & & & & \\
DMl, kg/day & 14.47 & 14.14 & 0.24 & 0.91 & 0.58 & 0.02 & 0.55 \\
DMl change ${ }^{1}, \mathrm{~kg}$ & 4.82 & 5.45 & 0.26 & 0.97 & 0.06 & 0.01 & 0.53 \\
NEl intake, Mcal/day & 24.32 & 23.75 & 0.40 & 1.53 & 0.58 & 0.03 & 0.32 \\
EB $^{2}$, Mcal/day & -7.64 & -8.06 & 1.52 & 5.71 & 0.63 & 0.02 & 0.33 \\
BCS & 3.35 & 3.40 & 0.12 & 0.16 & 0.66 & 0.04 & 0.22 \\
Days relative to expected calving $(+8$ to +28$)$ & & & & & & \\
BCS & 3.18 & 3.24 & 0.10 & 0.17 & 0.07 & 0.02 & 0.24 \\
BCS change & -0.28 & -0.30 & 0.09 & 0.32 & 0.57 & 0.03 & 0.25 \\
BW change ${ }^{4}, \mathrm{~kg}$ & -30.26 & -38.81 & 1.09 & 3.12 & 0.11 & 0.04 & 0.33
\end{tabular}

${ }^{1}$ Change = DMl 7 days after calving minus DMI on the day after calving, ${ }^{2}$ Calculated using National Research Council (2001) software, ${ }^{3}$ Change = BCS 28 days after calving minus BCS on the day of calving, ${ }^{4}$ Change $=$ BW 28 days after calving minus BW on the day after calving, BCS: body condition score, BW: body weight, DMI: dry matter intake, NEI: net energy intake, EB: energy balance, RMSE: root mean square error

The effects of the diets were significant $(P<0.05)$ for the propionate, butyrate and acetate to propionate ratio in the pre-partum period and for total acids, propionate and acetate to propionate ratio in the post-partum period. Wheat-based diets increased the propionate concentration whereas the acetate to propionate ratio was reduced. Notable increases in the concentrations of total volatile fatty acid, acetate, propionate, butyrate, iso-butyrate, valerate, and iso-valerate, and a decrease in the acetate to propionate ratio were recorded during the post-partum period for both diets. The $\mathrm{pH}$, VFA concentration and acetate to propionate ratio of rumen fluid for the pre- and post-partum periods are recorded in Table 4. 
Table 4 Characterization of the rumen environment of dairy cows fed corn- or wheat-based rations in the pre-partum period

\begin{tabular}{|c|c|c|c|c|c|c|c|c|c|c|}
\hline \multirow{3}{*}{ Item } & \multicolumn{5}{|c|}{ Pre-partum period } & \multicolumn{5}{|c|}{ Post-partum period } \\
\hline & \multicolumn{2}{|c|}{ Diet } & \multirow{2}{*}{ SE } & \multirow{2}{*}{ RMSE } & \multirow{2}{*}{$P$-value } & \multicolumn{2}{|c|}{ Diet } & \multirow{2}{*}{ SE } & \multirow{2}{*}{ RMSE } & \multirow{2}{*}{$P$-value } \\
\hline & Corn & Wheat & & & & Corn & Wheat & & & \\
\hline $\mathrm{pH}$ & 6.42 & 6.40 & 0.04 & 0.10 & 0.76 & 6.42 & 6.47 & 0.03 & 0.11 & 0.34 \\
\hline \multicolumn{11}{|l|}{ Volatile fatty acids (mmol/L) } \\
\hline Total & 110.32 & 109.66 & 1.87 & 5.94 & 0.80 & 128.68 & 133.33 & 1.29 & 4.09 & 0.02 \\
\hline Acetate & 72.70 & 69.40 & 1.54 & 4.89 & 0.15 & 81.03 & 81.81 & 0.83 & 2.62 & 0.51 \\
\hline Propionate & 21.50 & 23.24 & 0.57 & 1.79 & 0.04 & 29.16 & 32.01 & 0.81 & 2.58 & 0.02 \\
\hline Butyrate & 11.37 & 12.07 & 0.28 & 0.89 & 0.09 & 13.16 & 13.27 & 0.42 & 1.32 & 0.38 \\
\hline Iso-butyrate & 0.97 & 0.97 & 0.03 & 0.08 & 0.93 & 1.05 & 1.01 & 0.04 & 0.14 & 0.60 \\
\hline Valerate & 1.85 & 1.98 & 0.06 & 0.19 & 0.08 & 2.42 & 2.52 & 0.06 & 0.20 & 0.42 \\
\hline Iso-valerate & 1.90 & 1.95 & 0.07 & 0.22 & 0.61 & 2.13 & 2.19 & 0.07 & 0.23 & 0.02 \\
\hline Acetate to propionate ratio & 3.39 & 3.00 & 0.08 & 0.26 & $<0.01$ & 2.81 & 2.55 & 0.07 & 0.25 & 0.03 \\
\hline
\end{tabular}

RMSE: root mean square error

The effects of diets were non-significant for milk production and composition during the first week of lactation. However, cows fed on the wheat-based diet had numerically higher $(P>0.10)$ yields of fatcorrected and energy-corrected milk and all milk components during the first week of lactation (Table 5). Milk composition during the post-partum period did not differ $(P>0.10)$ between diets, but the cows fed on wheat produced more $(P<0.05)$ milk (Table 6$)$. The yields and concentrations of fat, protein and lactose were numerically greater $(P>0.10)$ for the wheat-based diet compared with the corn-based diet post-partum. The cows fed on the wheat diet tended $(P<0.10)$ to produce milk with a greater protein content $(33.2 \mathrm{vs}$. 31.2 $\mathrm{g} / \mathrm{kg}$ milk) and less $(P<0.01)$ milk urea nitrogen $(17.68 \mathrm{vs} 14.74 \mathrm{mg} / \mathrm{dl})$ compared with cows fed on the corn diet. A significant increase in milk production parameters was observed with time post-partum, except for protein for both diets. Diet to time interaction for lactose content and yield were significant post-partum.

Plasma concentrations of glucose, non-esterified fatty acid, calcium, and insulin recorded around calving are presented in Table 7 . Feeding wheat diets to the dairy cows increased $(P<0.05)$ the plasma concentrations of albumin and glucose but reduced $(P<0.05)$ those of triglyceride and non-esterified fatty acid post-partum. 
Table 5 Production and composition of milk produced during first seven days post-partum by dairy cows fed either corn or wheat-based rations in the pre-partum period

\begin{tabular}{|c|c|c|c|c|c|}
\hline \multirow{2}{*}{ Item } & \multicolumn{2}{|c|}{ Pre-partum diet } & \multirow{2}{*}{ SE } & \multirow{2}{*}{ RMSE } & \multirow{2}{*}{$P$-value } \\
\hline & Corn & Wheat & & & \\
\hline \multicolumn{6}{|l|}{ Yield, kg/day } \\
\hline Milk & 25.70 & 27.30 & 1.12 & 4.19 & 0.17 \\
\hline FCM & 31.13 & 35.70 & 2.21 & 8.28 & 0.23 \\
\hline ECM & 30.55 & 34.81 & 2.11 & 7.93 & 0.20 \\
\hline Fat & 1.24 & 1.41 & 0.11 & 0.43 & 0.29 \\
\hline Protein & 0.89 & 1.02 & 0.11 & 0.42 & 0.43 \\
\hline Lactose & 0.99 & 1.08 & 0.04 & 0.18 & 0.11 \\
\hline Total solid & 3.30 & 3.65 & 0.21 & 0.79 & 0.22 \\
\hline \multicolumn{6}{|c|}{ Composition, g/kg } \\
\hline Fat & 47.9 & 50.8 & 3.48 & 1.30 & 0.63 \\
\hline Protein & 35.9 & 37.2 & 4.54 & 1.70 & 0.83 \\
\hline Lactose & 38.9 & 39.6 & .94 & 0.35 & 0.59 \\
\hline Total solid & 130.4 & 132.5 & 6.05 & 2.26 & 0.79 \\
\hline MUN, mg/dl & 18.9 & 16.1 & 1.38 & 5.17 & 0.14 \\
\hline SCC & 4.3 & 3.1 & 0.13 & 4.91 & 0.22 \\
\hline
\end{tabular}

FCM: fat-corrected milk, ECM: energy-corrected milk, MUN: milk urea nitrogen, SCC: somatic cell count, RMSE: root mean square error

Table 6 Production and composition of milk produced by dairy cows fed corn- or wheat-based rations in the pre-partum period and for 28 days post-partum

\begin{tabular}{|c|c|c|c|c|c|c|c|}
\hline \multirow{2}{*}{ Item } & \multicolumn{4}{|c|}{ Pre-partum diet } & \multicolumn{3}{|c|}{$P$-value } \\
\hline & Corn & Wheat & SE & RMSE & Diet & Time & Diet $\times$ time \\
\hline \multicolumn{8}{|l|}{ Yield, kg/day } \\
\hline Milk & 31.04 & 33.09 & 1.03 & 4.23 & 0.04 & 0.001 & 0.57 \\
\hline FCM & 36.47 & 38.38 & 1.54 & 7.75 & 0.16 & 0.005 & 0.69 \\
\hline ECM & 35.83 & 37.88 & 1.49 & 6.42 & 0.12 & 0.002 & 0.50 \\
\hline Fat & 1.42 & 1.48 & 0.07 & 0.28 & 0.26 & 0.08 & 0.59 \\
\hline Protein & 0.96 & 1.09 & 0.06 & 1.12 & 0.48 & 0.12 & 0.33 \\
\hline Lactose & 1.25 & 1.30 & 0.04 & 0.19 & 0.78 & 0.001 & 0.06 \\
\hline Total solid & 3.97 & 4.13 & 0.14 & 0.62 & 0.56 & 0.001 & 0.11 \\
\hline \multicolumn{8}{|c|}{ Composition, g/kg } \\
\hline Fat & 44.6 & 45.5 & 2.02 & 9.02 & 0.81 & 0.030 & 0.47 \\
\hline Protein & 31.2 & 33.2 & 2.43 & 11.2 & 0.08 & 0.10 & 0.81 \\
\hline Lactose & 40.1 & 39.7 & 0.70 & 2.93 & 0.62 & 0.09 & 0.04 \\
\hline Total solid & 127.3 & 127.1 & 3.54 & 14.8 & 0.96 & 0.001 & 0.52 \\
\hline MUN, mg/dl & 17.7 & 14.7 & 0.87 & 4.95 & 0.04 & 0.07 & 0.94 \\
\hline SCC & 3.7 & 3.1 & 0.17 & 0.91 & 0.14 & 0.020 & 0.15 \\
\hline
\end{tabular}

FCM: fat-corrected milk, ECM: energy-corrected milk, MUN: milk urea nitrogen, SCC: somatic cell count, RMSE: root mean square error 
Table 7 Concentrations of plasma glucose, non-esterified fatty acid, calcium, and insulin of dairy cows fed corn or wheat-based diets between days -7 and +7 of the peri-partum period

\begin{tabular}{clcccc}
\hline Day & Diet & Glucose, $\mathrm{mg} / \mathrm{dL}$ & NEFA, mmol/L & Calcium, $\mathrm{mmol} / \mathrm{L}$ & Insulin, $\mathrm{pg} / \mathrm{mL}$ \\
\hline & Corn & $56.30 \pm 3.40$ & $0.24 \pm 0.03$ & $2.94 \pm 0.06$ & $504.4 \pm 27.6$ \\
-7 & Wheat & $60.79 \pm 3.40$ & $0.20 \pm 0.03$ & $3.08 \pm 0.06$ & $503.4 \pm 27.6$ \\
& RMSE & 7.11 & 0.16 & 0.10 & 27.6 \\
& $P$-value & 0.39 & 0.37 & 0.32 & 0.90 \\
& Corn & $56.47 \pm 4.05$ & $0.36 \pm 0.03$ & $2.73 \pm 0.07$ & $430.6 \pm 25.7$ \\
-1 & Wheat & $63.19 \pm 4.05$ & $0.31 \pm 0.03$ & $2.51 \pm 0.07$ & $491.4 \pm 25.7$ \\
& RMSE & 7.30 & 0.20 & 0.06 & 25.7 \\
& $P$-value & 0.20 & 0.27 & 0.14 & 0.01 \\
& Corn & $62.21 \pm 3.43$ & $0.61 \pm 0.07$ & $2.50 \pm 0.10$ & $407.9 \pm 25.6$ \\
0 & Wheat & $62.63 \pm 3.43$ & $0.63 \pm 0.07$ & $2.60 \pm 0.10$ & $431.1 \pm 25.6$ \\
& RMSE & 8.10 & 0.27 & 0.10 & 24.4 \\
& $P$-value & 0.93 & 0.87 & 0.38 & 0.50 \\
& Corn & $49.30 \pm 2.61$ & $0.60 \pm 0.07$ & $2.53 \pm 0.07$ & $326.0 \pm 19.3$ \\
+1 & Wheat & $49.29 \pm 2.61$ & $0.38 \pm 0.07$ & $2.63 \pm 0.07$ & $340.2 \pm 19.3$ \\
& RMSE & 7.77 & 0.19 & 0.13 & 30.3 \\
& $P$-value & 0.99 & 0.09 & 0.03 & 0.60 \\
& Corn & $40.02 \pm 2.33$ & $0.46 \pm 0.06$ & $2.82 \pm 0.13$ & $280.1 \pm 24.3$ \\
+7 & Wheat & $42.18 \pm 2.33$ & $0.43 \pm 0.06$ & $2.95 \pm 0.13$ & $286.8 \pm 24.3$ \\
& RMSE & 6.20 & 0.22 & 0.15 & 32.3 \\
& $P$-value & 0.66 & 0.82 & 0.26 & 0.84
\end{tabular}

NEFA: Non-esterified fatty acids, RMSE: root mean square error

Non-significant differences were noted between diets for plasma concentrations of insulin, cortisol, $\beta$ hydroxybutyric acid, cholesterol, and aspartate aminotransferase in the peri-parturient period (Table 8$)$. The wheat diet fed pre-partum increased serum cholesterol pre-partum $(P<0.05)$, increased the serum concentrations of non-esterified fatty acids, albumin and triglyceride post-partum $(P<0.05)$ and tended to also increase serum concentrations of glucose and calcium post-partum $(P<0.10)$ compared with the corn diet. Diet and time interactions were not significant for all the serum constituents. Cows fed the wheat diet had lower urinary $\mathrm{pH}$ pre-partum than cows fed the corn diet $(P<0.05)$. Glucose concentration increased slightly near parturition, whereas the insulin concentration decreased gradually from day -7 to day +7 for both diets. The non-esterified fatty acid concentration tended to decrease, whereas the calcium concentration increased within 24 hours of calving.

The regulation of feed intake in dairy cows is complex, and requires an understanding of the physical and physiological mechanisms along with the characteristics of the animal (Celi et al., 2017; Tahir et al., 2013) and of the environment (diet and temperature, humidity, etc.). This complexity becomes intensified during the peri-parturient period when cows to go through a transition phase (Ingvartsen \& Andersen, 2000; Hayirli \& Grummer, 2004). The hypothesis of this study was that the addition of a more acidogenic grain to pre-partum diets would promote the ruminal production of propionate and develop ruminal papillae for adequate absorption of VFA during ruminal fermentation (Esposito et al., 2014). This was expected to result in an improved energy balance during the peri-parturient period (Amanlou et al., 2008; Alamouti et al., 2009; Nikkhah et al., 2011). Cows fed the diet in which wheat replaced corn had greater body condition score and DMI pre-partum with no detected effect on energy balance. This reflects that the cows on wheat diets used the diet energy content efficiently to build up body reserves while keeping DMI at lower levels than cows fed corn diets pre-partum and that these body reserves were utilized economically to meet the energy demands while maintaining no difference in DMI on both diets post-partum. In most studies, altering the source of nonfibre carbohydrate in pre-partum diets resulted in no change in DMI during the peri-parturient period or in early to mid-lactation (Smith et al., 2005; Cabrita et al., 2009; Tahir et al., 2013). In addition, the higher production of propionate in wheat-fed cows altered the total amount of rumen-fermented carbohydrates, keeping the DMI at lower levels on wheat diets than in the corn diets with negative feed intake control 
signals. This suggested that the total amount of rumen-fermented carbohydrates, the level of intake, and the forage source were more important in regulating feed intake than the extent of grain acidogenicity. GualdrónDuarte and Allen (2018) suggested that a decrease in diet intake with highly fermentable starch was probably because of variations in hepatic metabolism.

Table 8 Metabolite and hormone concentrations in serum of dairy cows fed corn- or wheat-based rations in the peri-partum period

\begin{tabular}{|c|c|c|c|c|c|c|c|}
\hline & \multicolumn{4}{|c|}{ Diet } & \multicolumn{3}{|c|}{$P$-value } \\
\hline & Corn & Wheat & SE & RMSE & Diet & Time & Diet $\times$ time \\
\hline \multicolumn{8}{|l|}{ Pre-partum } \\
\hline Urinary $\mathrm{pH}$ & 6.90 & 6.62 & 0.10 & 1.10 & 0.02 & - & - \\
\hline Glucose, mg/dL & 56.67 & 58.86 & 3.50 & 7.17 & 0.27 & 0.24 & 0.12 \\
\hline Non esterified fatty acids, $\mathrm{mmol} / \mathrm{L}$ & 0.27 & 0.25 & 0.02 & 0.08 & 0.14 & 0.001 & 0.64 \\
\hline Beta hydroxy butyric acid, $\mathrm{mmol} / \mathrm{L}$ & - & - & - & & - & - & - \\
\hline Albumin, g/dL & 4.20 & 4.55 & 0.18 & 0.56 & 0.01 & 0.04 & 0.92 \\
\hline Blood urea nitrogen, $\mathrm{mg} / \mathrm{dL}$ & 14.15 & 12.60 & 0.63 & 2.89 & 0.10 & 0.001 & 0.22 \\
\hline Triglyceride, $\mathrm{mg} / \mathrm{dL}$ & 19.51 & 15.28 & 2.40 & 7.39 & 0.09 & 0.93 & 0.89 \\
\hline Cholesterol, mg/dL & 63.50 & 72.19 & 2.88 & 13.3 & 0.02 & 0.05 & 0.20 \\
\hline Calcium, $\mathrm{mmol} / \mathrm{L}$ & 2.97 & 3.15 & 0.05 & 0.79 & 0.12 & 0.01 & 0.17 \\
\hline Aspartate amino transferase, IU/L & 52.83 & 51.98 & 3.06 & 11.7 & 0.97 & 0.33 & 0.98 \\
\hline Insulin, pg/mL & 490.75 & 505.12 & 28.3 & 49.7 & 0.17 & 0.01 & 0.07 \\
\hline Cortisol, ng/mL & 12.50 & 13.54 & 1.31 & 2.13 & 0.59 & 0.13 & 0.28 \\
\hline \multicolumn{8}{|l|}{ Post-partum } \\
\hline Glucose, mg/dL & 46.41 & 48.82 & 2.62 & 8.40 & 0.07 & 0.01 & 0.99 \\
\hline Non esterified fatty acids, mmol/L & 0.41 & 0.36 & 0.05 & 0.23 & 0.04 & 0.01 & 0.48 \\
\hline Beta hydroxy butyric acid, mmol/L & 0.32 & 0.27 & 0.03 & 0.18 & 0.18 & 0.19 & 0.52 \\
\hline Albumin, g/dL & 3.65 & 3.99 & 0.14 & 0.48 & 0.01 & 0.01 & 0.28 \\
\hline Blood urea nitrogen, $\mathrm{mg} / \mathrm{dL}$ & & & - & & - & - & \\
\hline Triglyceride, $\mathrm{mg} / \mathrm{dL}$ & 19.89 & 15.61 & 1.15 & 7.57 & 0.01 & 0.81 & 0.33 \\
\hline Cholesterol, mg/dL & 100.45 & 105.14 & 3.98 & 16.5 & 0.93 & 0.001 & 0.29 \\
\hline Calcium, mmol/L & 2.76 & 2.85 & 0.03 & 0.70 & 0.09 & 0.001 & 0.87 \\
\hline Aspartate amino transferase, IU/L & 53.70 & 50.01 & 2.14 & 14.2 & 0.22 & 0.01 & 0.92 \\
\hline Insulin, pg/mL & 313.41 & 330.18 & 10.0 & 71.5 & 0.25 & 0.001 & 0.91 \\
\hline Cortisol, ng/mL & 14.45 & 15.33 & 1.50 & 1.23 & 0.69 & 0.001 & 0.44 \\
\hline
\end{tabular}

RMSE: root mean square error

Milk production is a function of DMI in dairy cows and most lactating species (e.g., Cabrita et al., 2009; Hetta et al., 2010). In the present study, post-partum DMI was not affected significantly by the post-partum treatment, and the milk yield of cows fed on wheat diets was greater. These findings are in line with previous studies (Alamouti et al., 2009), but contradict Smith et al. (2005), who suggested that the pre-partum grain source does not carry over effects of grain variability post-partum, and reported no differences in post-partum milk yield, milk component yields, and most milk component concentrations. A significant increase in milk yield and numerical increases in fat-corrected and energy-corrected milk yield on wheat diets could be the result of improved hepatic gluconeogenesis from a high propionate production and a low acetate to propionate ratio (Cabrita et al., 2009; Esposito et al., 2014) Further, the increased milk protein and reduced milk urea nitrogen data indicated an increased microbial protein flow to the small intestine owing to improved synchronization of rapidly degradable protein and starch (Herrera-Saldana et al., 1990). Albornoz et al. (2019) suggested that pronounced effects of fermentation of starch on milk energy output, energy balance 
and blood metabolites were visible in situations in which high starch diets were fed to cows during the dry period or immediately after parturition.

In the present study, most blood metabolites and hormones were not affected by the pre-partum cereal grain source during the peri-parturient period. The results were similar to those of Smith et al. (2008). Many studies showed significant increases in glucose levels (Amanlou et al., 2008; Alamouti et al., 2009; Nikkhah et al., 2011), in which plasma glucose increased in a curvilinear fashion around calving (day -7 to day +7 ) in response to feeding wheat grain pre-partum. In agreement with other studies (Van Hoeij et al., 2017), plasma insulin did not differ between treatments. Overall, the plasma insulin concentration was raised around calving, which showed a similar trend between plasma glucose and insulin levels. Hypoinsulinemia in the dairy cow during early lactation is part of an adaptation process from gestation to lactation. Further, the contrasting sources of grains failed to produce differences in the $\beta$-hydroxybutyric acid concentration. Increased plasma non-esterified fatty acid concentrations are indicative of the body energy balance of the animals around calving (day -1 to +1 ), which are related to the cleavage of triglyceride by lipases in the adipose tissue (Kuhla et al., 2016). In general, plasma non-esterified fatty acid concentrations are good indicators of body fat mobilization. The high metabolic priority of the mammary gland for milk production, accompanied by limited feed intake around parturition results in a high propensity to mobilize body fat reserves (Gross et al., 2013; Kuhla et al., 2016). However, significant changes in BCS were not observed during the peri-parturient period in the present study.

A primary finding of this study was that wheat diets reduced urinary $\mathrm{pH}$ owing to a drop in extracellular alkalinity or metabolic acidosis (Grünberg et al., 2011; Nikkhah et al., 2011; Babir et al., 2017). It is reasonable to assume that the lowered extracellular alkalinity might have activated the immune cells and all possible mechanisms of Ca supply (Horst et al., 1997). A second important finding was that the wheat diet maintained the plasma $\mathrm{Ca}$ levels above the hypocalcaemia threshold during the transition and around calving. The plasma $\mathrm{Ca}$ levels dropped rapidly one day before the expected calving and this decline was more visible for wheat diets. On the day of calving, plasma Ca levels were at their lowest points $(2.5 \mathrm{mmol} / \mathrm{L})$ for both diets with non-significant differences. However, within 24 hours of calving, in cows fed the wheat diets, Ca levels increased significantly more rapidly than for those fed the corn diets. Megahed et al. (2018) found that the plasma $\mathrm{Ca}$ fell below $2.15 \mathrm{mmol} / \mathrm{L}$ at least nine hours before calving, and this decrease continued for next 57 hours after calving in dairy cows fed an acidogenic diet. The present results support the findings of Megahed et al. (2018) in that the depression in plasma Ca starts well before the actual time of calving. This finding is opposite to the popular view that plasma $\mathrm{Ca}$ concentrations do not decrease until parturition. Megahed et al. (2018) added that the post-partum administration of Ca may be too late to make up the required $\mathrm{Ca}$, because the onset of colostrogenesis is $9-12$ hours before the actual time of parturition. Most studies that used a $\mathrm{Ca}$ supplement pre- or post partum failed to produce beneficial effects on the incidence and severity of post-partum hypocalcaemia (Kronqvist et al., 2011; Oetzel \& Miller, 2012; Blanc et al., 2014). Otzel and Miller (2012) showed the moderate effects of post-partum Ca supplementation on health, whereas those of Martinez et al. (2016a; 2016b) on multiparous dairy cows exhibited modest effects of oral $\mathrm{Ca}$ administration on reproductive performance and milk yield in high-producing cows. Nevertheless, the traditional practice of feed supplements pre- or post partum might have beneficial effects on $\mathrm{Ca}$ homeostasis and animal health and performance. Exogenous supplementation always requires additional financial and managemental frameworks to be adopted. The feeding plan, which already includes a solution to metabolic disorders such as hypocalcaemia in the peri-parturient diets, could be advantageous and may save time, labour, and extra cost in the long run.

\section{Conclusion}

Feeding wheat grain as a high acidogenic source of starch in the pre-partum diet increased ruminal propionate production and improved nitrogen utilization by lowering milk and blood urea nitrogen and increasing milk and milk protein. It could improve the plasma calcium status around the time of calving, thus lowering the chances of hypocalcaemia and favouring the smooth transition of multiparous dairy cows from gestation to lactation.

\section{Acknowledgment}

The authors thank the Ministry of Science and Technology of Iran, University of Tehran, and University of Zanjan.

\section{Authors' Contributions}

HMA and HA conceived and designed the study, which was performed by KR, MV and HMA. MNT and MZI analysed the data, and HMA, MNT and MZI wrote the manuscript.

\section{Conflict of Interest Declaration}


The authors declare that they have no competing interests.

\section{References}

Alamouti, H., Amanlou, H., Rezayazdi, K. \& Towhidi, A., 2009. Effects of pre-partum dietary carbohydrate source on metabolism and performance of primiparous Holstein cows during the peri-parturient period. Asian-Australasian J. Anim. Sci., 22, 1513-1520.

Albornoz, R., Harvatine, K.J. \& Allen, M., 2019. Diet starch concentration and starch fermentability affect energy intake and energy balance of cows in the early postpartum period. J. Dairy Sci. 102, 5161-5171.

Amanlou, H., Zahmatkesh, D. \& Nikkhah, A., 2008. Wheat grain as a prepartal cereal choice to ease metabolic transition from gestation into lactation in Holstein cows. J. Anim. Physiol. Anim. Nutr. 92, 605-613.

AOAC, 2000. AOAC official methods of analysis. Sections, 50, 905-992. Association of Official Analytical Chemists International, Gaithersburg, MD.

Babir, M., Atif, A. \& Rehman, A.U., 2017. Effect of pre-partum dietary cation-anion difference on the performance of transition Sahiwal cattle. The J. Anim. Plant Sci., 27, 1795-1805.

Baevre, L., Junkkarinen, L., Pedersen, J., Setälä, J. \& Sjaunja, L.O. 1988. A Nordic proposal for energy corrected milk (ECM) formula. International Committee for Recording the Productivity of Milk Animals (ICRPMA), Paris.

Blanc, C.D., Van der List, M., Aly, S.S., Rossow, H.A. \& Silvadel-Río, N., 2014. Blood calcium dynamics after prophylactic treatment of subclinical hypocalcaemia with oral or intravenous calcium. J. Dairy Sci. 97, 6901-6906.

Brog, R.A. 1971. Is fat-corrected milk sufficient. J. Dairy Sci. 54, 1137-1141.

Cabrita, A., Vale, J., Bessa, R., Dewhurst, R. \& Fonseca, A., 2009. Effects of dietary starch source and buffers on milk responses and rumen fatty acid biohydrogenation in dairy cows fed maize silage-based diets. Anim. Feed Sci. Technol. 152, 267-277.

Celi, P., Cowieson, A., Fru-Nji, F., Steinert, R., Kluenter, A.M. \& Verlhac, V., 2017. Gastrointestinal functionality in animal nutrition and health: New opportunities for sustainable animal production. Anim. Feed Sci. Technol., 234, 88-100.

DeGaris, P.J. \& Lean, I.J., 2008. Milk fever in dairy cows: A review of pathophysiology and control principles. Vet. J. 176, 58-69.

Drackley, J.K., 1999. Biology of dairy cows during the transition period: The final frontier? J. Dairy Sci. 82, $2259-2273$.

Esposito, G., Irons, P.C., Webb, E.C. \& Chapwanya, A., 2014. Interactions between negative energy balance, metabolic diseases, uterine health and immune response in transition dairy cows. Anim. Reprod. Sci. 144, 60-71.

Fox, D.G., Tedeschi, L., Tylutki, T., Russell, J., Van Amburgh, M., Chase, L., Pell, A. \& Overton, T., 2004. The Cornell net carbohydrate and protein system model for evaluating herd nutrition and nutrient excretion. Anim. Feed Sci. Technol. 112, 29-78.

Goff, J.P., 2008. The monitoring, prevention, and treatment of milk fever and subclinical hypocalcaemia in dairy cows. Vet. J. 176, 50-57.

Gross, J.J., Schwarz, F., Eder, K., van Dorland, H.A. \& Bruckmaier, R., 2013. Liver fat content and lipid metabolism in dairy cows during early lactation and during a mid-lactation feed restriction. J. Dairy Sci. 96, 5008-5017.

Grummer, R.R., Mashek, D.G. \& Hayirli, A., 2004. Dry matter intake and energy balance in the transition period. Vet. Clinic. Food Anim. Practice. 20, 447-470.

Grünberg, W., Donkin, S.S. \& Constable, P.D., 2011. Periparturient effects of feeding a low dietary cation-anion difference diet on acid-base, calcium, and phosphorus homeostasis and on intravenous glucose tolerance test in high-producing dairy cows. J. Dairy Sci. 94, 727-745

Gualdrón-Duarte, L.B. \& Allen, M.S., 2018. Fuels derived from starch digestion have different effects on energy intake and metabolic responses of cows in the postpartum period. J. Dairy Sci. 101, 5082-5091.

Hayirli, A. \& Grummer, R., 2004. Factors affecting dry matter intake pre-partum in relationship to etiology of peripartum lipid-related metabolic disorders: A review. Canadian J. Dairy Sci. 84, 337-347.

Herrera-Saldana, R., Gomez-Alarcon, R., Torabi, M. \& Huber, J., 1990. Influence of synchronizing protein and starch degradation in the rumen on nutrient utilization and microbial protein synthesis. J. Dairy Sci. 73, 142-148.

Hetta, M., Tahir, M. \& Swensson, C., 2010. Responses in dairy cows to increased inclusion of wheat in maize and grass silage based diets. Acta Agriculturae Scand. Sec. A. 60, 219-229.

Horst, R., Goff, J., Reinhardt, T. \& Buxton, D., 1997. Strategies for preventing milk fever in dairy cattle. J. Dairy Sci. 80, 1269-1280.

Ingvartsen, K.L. \& Andersen, J.B., 2000. Integration of metabolism and intake regulation: A review focusing on periparturient animals. J. Dairy Sci. 83, 1573-1597.

Kimura, K., Reinhardt, T. \& Goff, J., 2006. Parturition and hypocalcaemia blunts calcium signals in immune cells of dairy cattle. J. Dairy Sci. 89, 2588-2595.

Kronqvist, C., Emanuelson, U., Spörndly, R. \& Holtenius, K., 2011. Effects of pre-partum dietary calcium level on calcium and magnesium metabolism in peri-parturient dairy cows. J. Dairy Sci. 94, 1365-1373.

Kuhla, B., Metges, C. \& Hammon, H., 2016. Endogenous and dietary lipids influencing feed intake and energy metabolism of peri-parturient dairy cows. Domestic Anim. Endocrinol. 56, S2-S10.

Licitra, G., Hernandez, T. \& Van Soest, P., 1996. Standardization of procedures for nitrogen fractionation of ruminant feeds. Anim. Feed Sci. Technol. 57, 347-358.

Littell, R.C., Henry, P. \& Ammerman, C.B., 1998. Statistical analysis of repeated measures data using SAS procedures. J. Dairy Sci. 76, 1216-1231.

Martinez, N., Risco, C.A., Lima, F.S., Bisinotto, R. S., Greco, L. F., Ribeiro, E. S., Maunsell, F., Galvao, K. \& Santos, J.E.P., 2012. Evaluation of peripartal calcium status, energetic profile, and neutrophil function in dairy cows at low or high risk of developing uterine disease. J. Dairy Sci. 95, 7158-7172. 
Martinez, N., Sinedino, L.D.P., Bisinotto, R.S., Daetz, R., Lopera, C., Risco, C.A., Galvão, K. N., Thatcher, W.W. \& Santos, J.E.P., 2016a. Effects of oral calcium supplementation on mineral and acid-base status, energy metabolites, and health of postpartum dairy cows. J. Dairy Sci. 99, 8397-8416.

Martinez, N., Sinedino, L.D.P., Bisinotto, R.S., Daetz, R., Risco, C.A., Galvão, K.N., Thatcher, W.W. \& Santos, J.E.P., $2016 \mathrm{~b}$. Effects of oral calcium supplementation on productive and reproductive performance in Holstein cows. J. Dairy Sci. 99, 8417-8430

Megahed, A.A., Mark, Hiew, W.H., El Badawy, S.A. \& Constable, P.D., 2018. Plasma calcium concentrations are decreased at least 9 hours before parturition in multiparous Holstein-Friesian cattle in a herd fed an acidogenic diet during late gestation. J. Dairy Sci. 101, 1365-1378

Nikkhah, A., Ehsanbakhsh, F., Zahmatkesh, D. \& Amanlou, H., 2011. Prepartal wheat grain feeding improves energy and calcium status of peri-parturient Holstein heifers. Anim. 5, 522-527.

NRC., 2001. Nutrient requirements of dairy cattle. Seventh revised edition. National Academic Press, Washington DC.

Oetzel, G. R. \& Miller, B.E., 2012. Effect of oral calcium bolus supplementation on early-lactation health and milk yield in commercial dairy herds. J. Dairy Sci. 95, 7051-7065

Ottenstein, D. \& Bartley, D., 1971. Improved gas chromatography separation of free acids C2-C5 in dilute solution. Anal. Chem. 43, 952-955.

Plaizier, J., Krause, D., Gozho, G. \& McBride, B., 2008. Subacute ruminal acidosis in dairy cows: The physiological causes, incidence and consequences. The Vet. J. 176, 21-31.

Santos, J.E.P., Lean, I.J., Golder, H. \& Block, E., 2019. Meta-analysis of the effects of pre-partum dietary cation-anion difference on performance and health of dairy cows. J. Dairy Sci. 102, 2134-2154

Sharma, N., Singh, N. K., Singh, O. P., Pandey, V. \& Verma, P. K., 2011. Oxidative stress and antioxidant status during transition period in dairy cows. Asian Australasian J. Anim. Sci., 24, 479-484

Smith, K., Waldron, M., Drackley, J.K., Socha, M. \& Overton, T., 2005. Performance of dairy cows as affected by prepartum dietary carbohydrate source and supplementation with chromium throughout the transition period. J. Dairy Sci. 88, 255-263.

Smith, K., Waldron, M., Ruzzi, L., Drackley, J.K., Socha, M. \& Overton, T., 2008. Metabolism of dairy cows as affected by pre-partum dietary carbohydrate source and supplementation with chromium throughout the peri-parturient period. J. Dairy Sci. 91, 2011-2020.

Stanley, T.A., Cochran, R.C., Vanzant, E.S., Harmon, D.L. \& Corah, L.R. 1993. Periparturient changes in intake, ruminal capacity, and digestive characteristics in beef cows consuming alfalfa hay 2. J. Anim. Sci. 71, 788-795.

Tahir, M., Lund, P. \& Hetta, M., 2013. The effects of and interactions between the maturity of grass silage and concentrate starch source when offered as total mixed rations on the performance of dairy cows. Anim. 7, 580590.

Thurmond, M.C., 1990. A method to estimate the somatic cell count of milk from a mastitic quarter using composite somatic cell count. Canadian J Vet. Res. Revue canadienne de recherche veterinaire 54, 190-194.

Van Hoeij, R., Dijkstra, J., Bruckmaier, R., Gross, J.J., Lam, T.J., Remmelink, G., Kemp, B. \& Van Knegsel, A., 2017. Consequences of dietary energy source and energy level on energy balance, lactogenic hormones, and lactation curve characteristics of cows after a short or omitted dry period. J. Dairy Sci. 100, 8544-8564.

Van Soest, P.J., Robertson, J. \& Lewis, B., 1991. Methods for dietary fibre, neutral detergent fibre, and nonstarch polysaccharides in relation to animal nutrition. J. Dairy Sci. 74, 3583-3597.

Wadhwa, D., Beck, N., Borgida, L., Dhanoa, M. \& Dewhurst, R.J., 2001. Development of a simple in vitro assay for estimating net rumen acid load from diet ingredients. J. Dairy Sci. 84, 1109-1117.

Wankhade, P.R., Manimaran, A., Kumaresan, A., Jeyakumar, S., Ramesha, K., Sejian, V., Rajendran, D. \& Varghese, M.R., 2017. Metabolic and immunological changes in transition dairy cows: A review. Vet. World 10, 1367-1377.

Wildman, E., Jones, G., Wagner, P., Boman, R., Troutt Jr, H. \& Lesch, T., 1982. A dairy cow body condition scoring system and its relationship to selected production characteristics. J. Dairy Sci. 65, 495-501 